\title{
FAKTOR-FAKTOR YANG MEMPENGARUHI VARIASI TARIF PAJAK EFEKTIF PERUSAHAAN: STUDI TERHADAP PERUSAHAAN YANG TERDAFTAR DI BEI TAHUN 2002 - 2006
}

\author{
Gatot Soepriyanto \\ Jurusan Akuntansi, Fakultas Ekonomi dan Komunikasi, BINUS University \\ Jl. K.H. Syahdan No. 9, Palmerah, Jakarta Barat 11480 \\ gsoepriyanto@binus.edu
}

\begin{abstract}
This paper analyzes the determinants of variability in corporate effective tax rates (ETRs) in a multivariate framework, using 2002 - 2006 Indonesian listed companies' micro-level data. Specifically, I examined the association between effective tax rates (ETRs), firm size and variable proxying for firm's capital structures and asset mix while controlling from profitability. This study's present evidence that ETRs are associated with the asset mix (level of capital intensity and inventory intensity) and return on assets. However, results also show that ETRs are not associated with size and firm's capital structure. Additionally, I controlled industry membership in sensitivity analysis because these firm specific characteristics might differ systematically by industry. To ensure the robustness of the result, diagnostic check was also performed. Related to the 2008 tax law amandement, this research can contribute to tax authority in order to identify firms that still have the potential to pay more taxes by looking at their capital intensity and inventory intensity.
\end{abstract}

Keywords: Effective tax rates, firm size and asset mix

\begin{abstract}
ABSTRAK
Penelitian ini bertujuan menganalisis faktor-faktor yang menentukan keberagaman tarif pajak efektif perusahaan dengan menggunakan model multiavariat pada data tahun 2002-2006 terhadap perusahaan yang terdaftar di Bursa Efek Indonesia. Penelitian dilakukan dengan menggunakan variabel tarif pajak efektif, ukuran perusahaan, struktur permodalan, kombinasi aset serta profitabilitas. Hasil dari penelitian ini menunjukkan bahwa tarif pajak efektif perusahaan dipengaruhi oleh kombinasi aset dan profitabilitas perusahaan. Untuk meningkatkan realibilitas hasil penelitian, analisis sensitivitas terhadap jenis industri dan uji kekokohan model juga dilakukan. Terakhir, terkait dengan perubahan Undang-Undang Perpajakan, penelitian ini berkontribusi terhadap regulator dalam hal mengidentifikasi jenis perusahaan mana yang masih memungkinkan untuk membayar pajak lebih besar lagi, dengan melihat kombinasi aset yang dimilikinya.
\end{abstract}

Kata kunci: Tarif Pajak Efektif, ukuran perusahaan dan kombinasi asset 


\section{PENDAHULUAN}

Reformasi bidang perpajakan yang dilakukan oleh pemerintah mencapai klimaksnya pada saat pengesahan Rancangan Undang-Undang (RUU) Pajak Penghasilan (PPh) tahun 2008 oleh Dewan Perwakilan Rakyat (DPR) pada 17 Juli 2008 yang lalu. Di antara beberapa perubahan yang ada, salah satu perubahan yang signifikan adalah penerapan tarif PPh Badan secara tunggal sebesar 28\% pada tahun 2009 dan 25\% pada tahun 2010, berbeda dengan tarif PPh badan yang berlaku sekarang ini, yaitu tarif progresif sebesar 10\% untuk penghasilan kena pajak (PKP)—sampai dengan 50 juta, 15\% untuk PKP 50 juta sampai 100 juta dan 30\% untuk PKP lebih dari 100 juta. Direktorat Jenderal Pajak (Ditjen Pajak) dan DPR berpendapat bahwa usulan penerapan tarif tunggal ini akan membuat iklim investasi dalam negeri lebih kompetitif sekaligus memudahkan aparat dalam melakukan pengawasan pajak.

Di sisi yang lain, dampak perubahan UU PPh ini dapat berakibat adanya potensi kerugian negara sebesar Rp40,8 triliun, yang Rp15,5 triliun di antaranya dikarenakan penurunan tarif tertinggi $\mathrm{PPh}$ Badan seperti dijelaskan di atas. Namun demikian, pemerintah tetap optimis bahwa kerugian di atas dapat tertutupi melalui peningkatan penerimaan pajak yang didapat melalui pertumbuhan faktor ekonomi, peningkatan kepatuhan, peningkatan penerimaan sektor tertentu, perluasan basis pajak (ekstensifikasi) dan extra effort.

Penelitian ini dapat memberikan kontribusi terhadap upaya pemerintah dalam menutup potensi kerugian negara di atas, dengan melakukan identifikasi terhadap faktor-faktor yang mempengaruhi tarif pajak efektif (TPE) perusahaan-perusahaan di Indonesia yang masih memiliki potensi pembayaran pajak lebih, khususnya perusahaan yang terdaftar di Bursa Efek Indonesia (BEI). Dengan teridentifikasinya faktor-faktor tersebut, maka Ditjen Pajak dapat melihat karakteristik tertentu dari perusahaan-perusahaan guna dijadikan fokus dalam upaya peningkatan kepatuhan dan perluasan basis pajak.

Studi ini menggunakant TPE sebagai variable dependen (dependent variable) yang menjadi proksi besar kecilnya pembayaran pajak perusahaan. TPE dihitung dengan membandingkan biaya pajak lancar (current tax expense) dengan laba akuntansi perusahaan sebelum pajak (earnings before tax). Mayoritas penelitian mengenai TPE menggunakan perhitungan di atas, antara lain: Stickney \& McGee, (1982); Callihan (1994), Gupta \& Newberry (1997) serta Mills, Erickson \& Maydew (1998). TPE menjadi bahan diskusi yang menarik karena TPE secara ringkas menunjukkan efektivitas perencanaan pajak dan insentif pajak dalam satu perhitungan yang mudah dilakukan. Lebih lanjut, guna melihat faktor-faktor apa saja yang mempengaruhi adanya variasi TPE antar perusahaan, akan digunakan juga beberapa variabel independen (independent variable) yang berkaitan dengan karakteristik perusahaan, antar lain ukuran perusahaan (size), bauran asset (asset mix), rasio hutang jangka panjang terhadap modal (leverage) dan tingkat kembalian aset terhadap modal (return on asset) sebagai variabel kontrol.

Dengan menggunkan uji regresi berganda terhadap 80 sampel perusahaan selama periode 2002-2006 (total 400 obeservasi - firm-year data), disimpulkan bahwa perbedaan TPE perusahaan disebabkan adanya variasi proporsi bauran aset berupa perbandingan antara aset tetap dan sediaan terhadap total aset (capital intensity dan inventory intensity). Lebih lanjut, studi ini tidak menemukan adanya hubungan yang signifikan antara tarif pajak efektif perusahaan dengan besar kecilnya perusahaan dan tingkat besaran hutang jangka panjang terhadap total aset.

\section{Tinjauan Pustaka}

Tarif pajak efektif perusahaan sudah menjadi objek penelitian yang menarik sejak tahun '80an. Hal ini tidak mengherankan, karena para peneliti berkeyakinan bahwa perusahaan berusaha untuk memaksimalkan laba, salah satunya dengan cara menekan biaya pajak yang mereka bayarkan. 
Mills, Erickson \& Maydew (1998) berpendapat bahwa perusahaan yang mengeluarkan dana lebih besar untuk konsultan perencanaan pajak akan cenderung memiliki tarif pajak efektif yang rendah. Dhaliwal, Gleason \& Mills (2004) menemukan bukti yang kuat bahwa perusahaan melakukan manajemen laba via biaya pajak dengan cara memanipulasi perubahan tarif pajak efektif di kuartal ketiga dan keempat pelaporan keuangan. Schmidt (2006) mendukung pendapat tersebut dengan menemukan bukti bahwa perubahan tarif pajak efektif memiliki hubungan (korelasi) dengan laba di masa depan (future earnings).

Studi yang dilakukan Stickney \& McGee (1982) menemukan bahwa tarif pajak efektif perusahaan dipengaruhi oleh intensitas besar kecil modal usaha, seberapa besar operasi perusahaan di luar negeri, ukuran perusahaan dan proporsi hutang yang dimiliki perusahaan. Gupta \& Newberry (1997) menemukan bahwa tarif pajak efektif perusahaan dipengaruhi oleh ukuran perusahaan, struktur permodalan, asset mix dan tingkat keuntungan yang dicetak perusahaan.

Di Indonesia sendiri, sepanjang pengetahuan penulis, belum ada penelitian yang mengaitkan tarif pajak efektif dengan karakteristik perusahaan. Penelitian mengenai pajak di Indonesia antara lain berisi tentang perencanaan pajak dan kaitannya dengan praktik manajemen laba dalam rangka meminimalkan biaya pajak. Ini bisa dilihat dari misalnya: Wulandari, Kumalahadi \& Prasetyo (2004), yang menemukan bukti bahwa perusahaan manufaktur di BEI melakukan manajemen laba menjelang diberlakukannya undang-undang perpajakan tahun 2000 serta Radianto (2004) yang meneliti tentang efisiensi perusahaan bank yang terdaftar di BEI sebelum dan sesudah diberlakukannya undang-undang perpajakan tahun 2000. Atas minimnya, penelitian di bidang perpajakan di Indonesia, dengan demikian hasil dari penelitian ini diharapkan dapat memberikan kontribusi tambahan bagi literatur perpajakan di Indonesia, khususnya penelitian empiris dengan menggunakan data-data skunder yang tersedia secara publik.

\section{Pengembangan Hipotesis}

Kendati perusahaan-perusahaan membayar pajak dengan tarif normal yang sama (30\% untuk penghasilan di atas 100 juta menurut UU No. 17 tahun 2000 tentang Pajak Penghasilan), beberapa perusahaan sebenarnya membayar pajak dengan tarif pajak efektif yang lebih tinggi/rendah dari tarif tersebut. Hal ini dimungkinkan karena adanya perbedaan perlakuan antara pencatatan akuntansi dan perpajakan serta adanya perbedaan karakteristik bisnis perusahaan. Sebagai contoh, perusahaan yang menggunakan pembiayaan mayoritas dari pinjaman akan mencatat tarif pajak efektif dan laba per saham lebih besar dengan perusahaan yang menggunakan model pembiayaan mayoritas lewat penerbitan saham. Hal ini dikarenakan biaya bunga dari pinjaman tersebut merupakan salah satu komponen pengurang penghasilan kena pajak, sehingga laba sebelum pajak juga menjadi lebih rendah dibandingkan dengan perusahaan yang menggunakan pembiayaan mayoritas lewat penerbitan saham.

Oleh karena itu menarik untuk diteliti lebih lanjut, apakah memang perbedaan tarif pajak antarperusahaan ini benar-benar terjadi di Indonesia. Pertanyaan ini sangat penting untuk dijawab untuk mengetahui karakteristik perusahaan model apa yang masih memiliki tarif pajak efektif tinggi (rendah), sehingga pemerintah bisa mempertimbangkan pemberian insentif (disinsentif) pajak yang tepat. Lebih jauh lagi, dalam kaitannya dengan karakteristik industri, di mana perusahaan tersebut berada, penting juga untuk dilakukan sebuah penelitian untuk menuntaskan perdebatan mengenai bagaimana sebaiknya peraturan pajak diberlakukan—apakah ke arah kebijakan pro sektor industri atau kebijakan yang seragam bagi semua industri?

Gupta \& Newberry (1997) dalam penelitiannya terhadap faktor-faktor yang mempengaruhi perbedaan TPE di Amerika, di periode sebelum dan sesudah reformasi pajak tahun 1986 di Amerika Serikat, menemukan bahwa, perbedaan TPE perusahaan dipengaruhi secara positif oleh proporsi sediaan dengan total aset (inventory intensity) dan tingkat kembalian aset. Selain itu mereka juga 
mendokumentasikan hubungan negatif antara TPE perusahaan dengan proporsi hutang jangka panjang terhadap aset, proporsi aset tetap bersih terhadap total aset (capital intensity) dan besar kecilnya ukuran perusahaan.

Para pendukung teori kos politik (political cost theory) meyakini bahwa pajak merupakan salah satu kos politik yang harus dibayar orang perusahaan berskala besar. Ini dimungkinkan karena perusahaan besar akan memiliki kecenderungan untuk mendapat sorotan lebih (more political visibility) dari publik dan pemerintah. Oleh karena itu perusahaan berskala besar akan cenderung untuk mempunyai tarif pajak efektif yang rendah guna memberi kesan patuh terhadap peraturan perpajakan (Watts \& Zimmerman, 1986 h.235). Dengan demikian hipotesis pertama dari penelitian ini adalah sebagai berikut (dinyatakan dalam hipotesis alternatif):

$\mathrm{H}_{1}$ : Semakin besar ukuran perusahaan maka tarif pajak efektif perusahaan juga akan semakin kecil.

Lebih lanjut, Stickney \& McGee (1982) dan Gupta \& Newberry (1992) berpendapat bahwa tarif pajak efektif memiliki hubungan yang erat dengan struktur modal dan bauran aset (asset mix) perusahaan. Ini bisa dilihat dari antara lain besar kecilnya proporsi aset tetap dan sediaan terhadap total aset. Semakin besar (kecil) proporsi aset tetap terhadap total aset, maka semakin kecil (besar), TPE yang dimiliki oleh perusahaan. Hal ini dimungkinkan karena biaya depresiasi aset tetap bisa dijadikan tax shield dalam perhitungan penghasilan kena pajak perusahaan. Hal tersebut berbeda dengan argumen proporsi sediaan terhadap total aset, di mana semakin besar inventory intensity maka semakin besar pula TPE perusahaan, karena sediaan tidak dapat diperlakukan sebagai tax shield seperti halnya aset tetap. Dengan demikian hipotesis kedua dan ketiga dari penelitian ini adalah sebagai berikut (dinyatakan dalam hipotesis alternatif):

$\mathrm{H}_{2}$ : Semakin besar proporsi aset tetap bersih dengan total aset (capital intensity) suatu perusahaan maka tarif pajak efektif perusahaan juga akan semakin kecil.

$\mathrm{H}_{3}$ : Semakin besar proporsi sediaan dengan total aset (inventory intensity) suatu perusahaan maka tarif pajak efektif perusahaan juga akan semakin besar.

Dalam kaitannya dengan komposisi kepemilikan, semakin dominannya posisi seorang pemegang saham, maka perusahaan akan cenderung memiliki tarif pajak efektif yang rendah, karena adanya insentif bagi mereka untuk mengurangi biaya pajak dengan tujuan menaikkan laba yang dilaporkan (Klassen, 1996). Berkaitan dengan proporsi hutang jangka panjang dan modal, perusahaan yang memiliki proporsi hutang jangka panjang dan modal lebih besar (kecil), akan memiliki TPE yang lebih kecil (besar). Ini dikarenakan adanya efek biaya pembayaran bunga pinjaman yang dapat digunakan sebagai biaya pengurang dalam penentuan penghasilan kena pajak perusahaan. Dengan demikian hipotesis keempat dari penelitian ini adalah sebagai berikut (dinyatakan dalam hipotesis alternatif):

$\mathrm{H}_{4}$ : Semakin besar proporsi hutang jangka panjang dengan total aset (leverage) suatu perusahaan maka tarif pajak efektif perusahaan juga akan semakin kecil.

\section{METODE}

\section{Proses Pengumpulan Data}

Pengumpulan data dilakukan dengan cara melakukan tabulasi data sekunder berupa laporan keuangan perusahaan yang terdaftar di BEI dalam periode 2002-2006. Periode tersebut dipilih dikarenakan berada di periode setelah penerapan tarif pajak perusahaan yang baru via Undang-Undang No. 17/2000 tentang pajak penghasilan, yang mulai diberlakukan 1 Januari 2001. Periode tahun 2001 
tidak dimasukkan dalam periode penelitian karena periode tersebut adalah periode transisi yang kerap digunakan oleh perusahaan untuk melakukan manajemen laba guna mengindari biaya pajak yang lebih besar (Wulandari, Kumalahadi \& Prasetyo, 2004).

Konsisten dengan penelitian sebelumnya (Gupta \& Newberry, 1992), untuk bisa masuk dalam sampel penelitian, perusahaan haruslah membukukan laba sebelum pajak (tidak mencatat rugi sebelum pajak) dan mencatat biaya pajak lancar selama 5 tahun periode observasi, dengan tujuan agar TPE dapat diinterpretasikan secara tepat. TPE akan sulit diintepretasikan apabila: (1) perusahaan memiliki laba sebelum pajak yang negatif (rugi); (2) perusahaan mempunyai manfaat pajak bukan biaya pajak; dan/atau (3) perusahaan memiliki kedua-duanya. Dalam kondisi (1) dan (2) TPE akan menjadi negatif, dan dalam kondisi (3) TPE menjadi positif, padahal perusahaan tidak membayar pajak.Selain itu perusahaan yang bergerak di sektor perbankan juga dikeluarkan dari sampel penelitian ini. Dari 436 perusahaan yang terdaftar di BEI per 31 Desember 2007, jumlah perusahaan yang memenuhi kriteria di atas sebanyak 80 perusahaan. Sehingga total observasi selama 5 periode adalah sebanyak 400 observasi. Data yang digunakan untuk perhitungan TPE dan karakteristik ekonomi perusahaan seluruhnya diambil dari basis data OSIRIS.

Lebih lanjut, perusahaan-perusahaan yang ada di dalam sampel berasal dari beberapa subindustri. Tabel 1 berikut ini menunjukkan ringkasannya:

Tabel 1. Distribusi Sampel Perusahaan Berdasar Industri

\begin{tabular}{ccccccccc}
\hline Industry & $\begin{array}{c}\text { Aneka } \\
\text { Industri }\end{array}$ & $\begin{array}{c}\text { Barang } \\
\text { Konsumsi }\end{array}$ & $\begin{array}{c}\text { Dasar \& } \\
\text { Kimia }\end{array}$ & $\begin{array}{c}\text { Infrastruktur, } \\
\text { Utilitas \& } \\
\text { Transportasi }\end{array}$ & $\begin{array}{c}\text { Perdagangan } \\
\text { dan Jasa }\end{array}$ & Pertanian & $\begin{array}{c}\text { Properti } \\
\text { dan Estat } \\
\text { Real }\end{array}$ & Pertambangan \\
\hline Jumlah & 7 & 18 & 18 & 5 & 20 & 2 & 8 & 2 \\
\hline
\end{tabular}

\section{Model dan Variabel}

Konsisten dengan literatur yang berkaitan dengan tarif pajak efektif dan karakteristik pajak perusahaan (Stickney \& McGee, 1982; Gupta \& Newberry, 1997), model empiris yang digunakan adalah sebagai berikut:

$$
T P E_{i t}=\beta_{0}+\beta_{1} \operatorname{SIZE}_{i t}+\beta_{2} L E V_{i t}+\beta_{3} C A P I N T_{i t}+\beta_{4} I N V I N T_{i t}+\beta_{5} R O A_{i t}+\epsilon
$$

Di mana:

Variabel Dependen:

TPE =tarif pajak efektif, yaitu biaya pajak lancar (current tax expense) dibagi dengan laba (akuntansi) sebelum pajak (earnings before tax);

Variabel Uji:

SIZE = natural log dari total aset

LEV = Leverage yaitu hutang jangka panjang dibagi dengan total aset

CAPINT = Capital intensity yaitu aset tetap bersih dibagi dengan total aset

INVINT = Inventory intensity yaitu sediaan dibagi dengan total aset

Variabel Kontrol:

ROA = Return on Assets/tingkat kembalian aset yang didapat dari laba sebelum pajak dibagi dengan total aset, sebagai proksi dari tingkat profitabilitas perusahaan.

$\in \quad=$ error term

Sementara $i$ menunjukkan perusahaan dan $t$ tahun observasi. 
Lebih lanjut, untuk mengetahui apakah ada kaitan antara variabel dependen (TPE) dengan variabel independen (SIZE, LEV, CAPINT, INVINT dan ROA), uji tes statistis berupa cross sectional regression akan dilakukan. Jika ada kaitan antara variabel dependen dengan variabel independen, maka koefisien regresi pada variabel independen akan menunjukkan hasil yang berbeda secara signifikan dari $\mathrm{H}_{0}$ (dengan demikian $\mathrm{H}_{0}$ ditolak). Selanjutnya, semua perhitungan $t$-hitung dan level signifikan didasarkan atas White (1980) standar error guna menghindari masalah heterokedasticity dan meningkatkan kekuatan hasil uji statistisnya.

Selain melakukan uji hipotesis, penelitian ini juga akan melakukan uji asumsi klasik (classical linier regression test) berupa uji heterokedastisitas, uji autokorelasi, uji multikolinearitas dan uji normalitas untuk memastikan bahwa hasil uji hipotesisnya kokoh (robust).

\section{HASIL DAN PEMBAHASAN}

\section{Statistik Deskriptif}

Tabel 2 menggambarkan stastistik deskriptif TPE sebagai variabel independen dan beberapa karakteristik ekonomi perusahaan sebagai variabel dependen. Panel A Tabel 2 menggambarkan mean TPE dari sampel perusahaan, yaitu sebesar $30,70 \%$ yang berada sedikit di atas tarif pajak normal (statutory rate) badan yang sebesar 30\%. Sementara frekuensi TPE yang kurang dari 10\% sebanyak 41 observasi atau 10,25\%, TPE yang berada di antara 10\% dan tarif pajak normal adalah 150 observasi (37,50\%) dan TPE yang berada di atas tarif pajak normal sebanyak 170 observasi (42,50\%).

Dalam kaitannya dengan statistik deskriptif variabel independen, dapat dilihat di panel B Tabel 2, bahwa mean (median) variabel SIZE atau ukuran perusahaan adalah 13,63 (13,49), yang menunjukkan bahwa ukuran perusahaan (total aset) di dalam sampel penelitian memiliki ukuran yang relatif homogenus yaitu perusahaan-perusahaan yang berskala besar. Sementara untuk mean (median) variabel LEV yang dihitung dari proporsi hutang jangka panjang terhadap total aset adalah $0,11(0,03)$ yang menunjukkan bahwa secara rata-rata proporsi hutang jangka panjang terhadap modal perusahaan adalah sebesar 11\%, sebuah proporsi yang dapat dikategorikan relatif rendah.

Tabel 2. Statistik Deskriptif Untuk Tarif Pajak Efektif dan Variabel Independen Selama Periode Observasi

\begin{tabular}{ll}
\hline Panel A: Tarif Pajak Efektif (TPE) & \\
\hline & $\begin{array}{l}2002-2005 \\
(\mathrm{n}=80 \text { perusahaan; } \\
\end{array}$ \\
\cline { 2 - 2 } Distribusi (dalam \%) & \multicolumn{1}{c}{ TPE } \\
\hline Mean & 30,70 \\
Standar Deviasi (standard deviation) & 17,81 \\
Nilai tengah (median) & 30,29 \\
Frekuensi (\% dalam n) & \\
TPE kurang dari 10\% & $41(10,25)$ \\
TPE antara 10\% dan tarif pajak statutori & $150(37,50)$ \\
TPE di atas tarif pajak statutori & $170(42,50)$
\end{tabular}




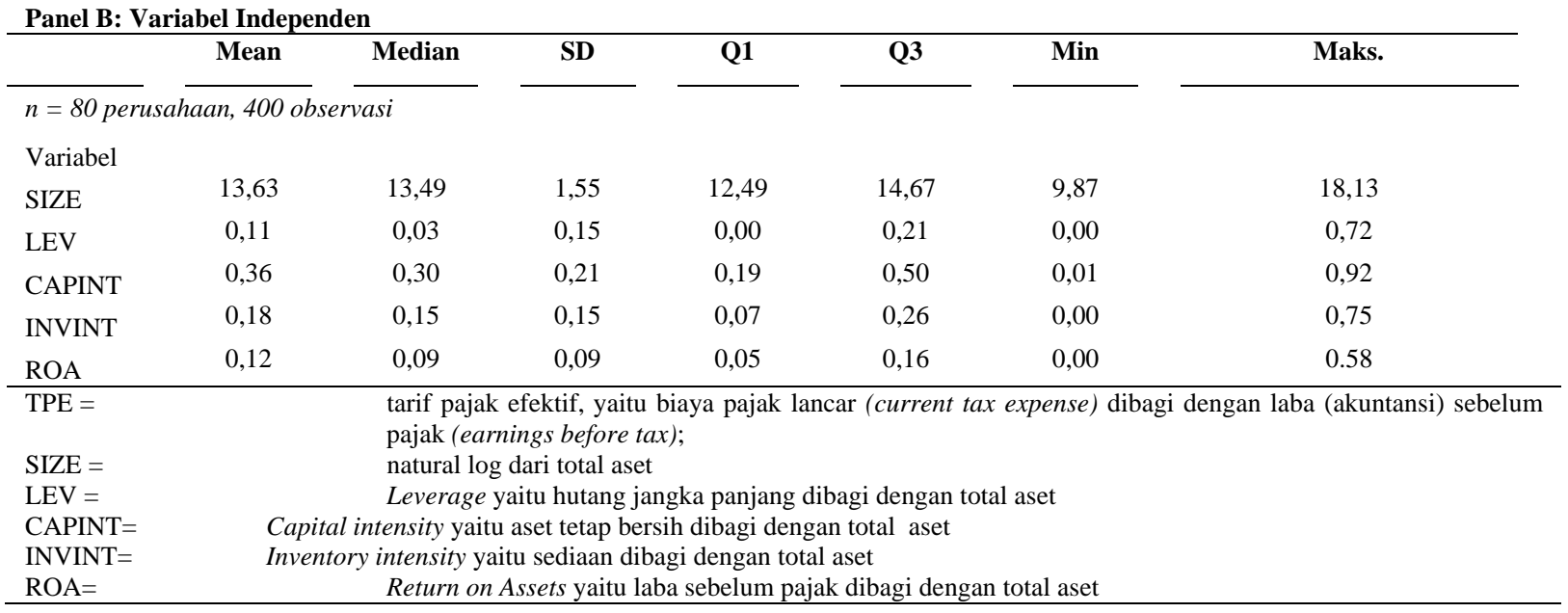

Selanjutnya, mean (median) variabel CAPINT adalah 0,36 $(0,30)$ yang menunjukkan bahwa secara rata-rata, intensitas penggunaan aset tetap pada perusahaan sampel sebesar $36 \%$ dibandingkan dengan total aset, sebuah angka yang relatif tinggi. Untuk variabel INVINT mean (median) adalah 0,18 $(0,15)$ yang berarti secara rata-rata perusahaan di dalam sampel memiliki sediaan sebesar $18 \%$ dari proporsi total aset. Terakhir, untuk variabel $R O A$ mean (median) adalah $0,12(0,09)$ yang berarti secara rata-rata, 1 rupiah aset yang digunakan perusahaan di dalam sampel dapat menghasilkan laba sebelum pajak sebesar 12 rupiah.

\section{Hasil Uji Regresi}

Tabel 3. Hasil Uji Regresi Terhadap Tarif Pajak Efektif sebagai Variabel Dependen dengan Karakteristik Perusahaan Sebagai Variabel Independen

\begin{tabular}{|c|c|c|c|c|c|}
\hline \multicolumn{6}{|c|}{ 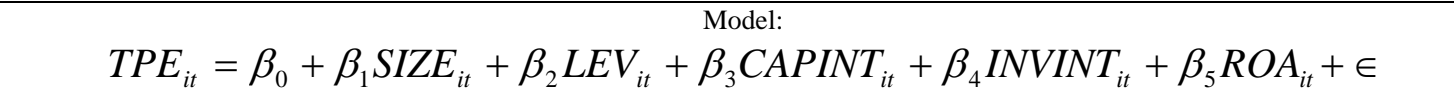 } \\
\hline Variabel $^{\mathrm{a}}$ & Tanda Prediksian & Koefisien Regresi & Standar Error & t-hitung ${ }^{\mathrm{b}}$ & Prob-t \\
\hline Konstanta & & 0,441 & 0,066 & 6,677 & 0,000 \\
\hline SIZE & - & $-0,005$ & 0,005 & $-1,032$ & 0,151 \\
\hline LEV & - & $-0,079$ & 0,073 & $-1,080$ & 0,140 \\
\hline CAPINT & - & $-0,135$ & 0,048 & $-2,837$ & $0,002 *$ \\
\hline INVINT & + & 0,103 & 0,063 & 1,648 & $0,050^{* *}$ \\
\hline ROA & + & $-0,194$ & 0,101 & $-1,925$ & $0,028 * *$ \\
\hline \multicolumn{6}{|c|}{$\begin{array}{l}\text { Adjusted } r^{2}=0,071 \\
\text { F-stat }=6,99\end{array}$} \\
\hline 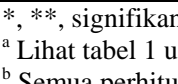 & dan 5\% (uji 1 ara & led test). & 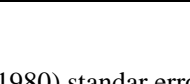 & & \\
\hline
\end{tabular}

Tabel 3 menunjukkan hasil uji regresi variabel dependen terhadap variabel independen dengan menggunakan model uji regresi di persamaan (1) yang telah didiskusikan sebelumnya. Koefisien determinasi disesuaikan (adjusted $\mathrm{r}^{2}$ ) sebesar 0,071 yang berarti bahwa variasi di dalam variabel dependen (TPE) dapat dijelaskan oleh variabel independen sebesar 7,1\%. Selanjutnya, dari hasil uji regresi pada tabel 3, dapat dilihat bahwa koefisien estimasi regresi untuk variabel SIZE dan $L E V$, tidak signifikan (t-hitung -1,032 dan t-hitung -1,080 dengan uji 1 arah) yang berarti bahwa ukuran besar kecilnya perusahaan dan besar kecilnya proporsi hutang jangka panjang terhadap aset - bukan merupakan faktor yang mempengaruhi variasi di dalam TPE. Hasil tersebut berbeda dengan apa yang telah dihipotesiskan di dalam $\mathrm{H}_{1}$ dan $\mathrm{H}_{4}$. 
Alasan mengapa SIZE bukan variabel yang mempengaruhi besar kecilnya TPE perusahaan dapat dijelaskan dengan fakta bahwa ukuran perusahaan di dalam sampel relatif sama (mayoritas adalah perusahaan-perusahaan beraset besar - lihat Tabel 2). Dengan tidak ada variasi ukuran perusahaan yang signifikan di dalam sampel diduga menjadi penyebab tidak adanya perbedaan TPE antarperusahaan (Stickney \& McGee, 1982; Shevlin \& Porter, 1992). Sementara penjelasan mengapa LEV bukan merupakan faktor yang mempengaruhi variasi pada TPE dapat dilihat berdasarkan fakta bahwa rata-rata proporsi hutang jangka panjang terhadap perusahaan adalah relatif rendah $(0,11$ atau 11\% dari total aset - lihat Tabel 2). Dengan leverage yang relatif rendah tersebut, perusahaanperusahaan di dalam sampel tidak dapat memanfaatkan insentif biaya bunga sebagai komponen pengurang pajak (tax shield) secara maksimal yang pada akhirnya tidak dapat menjelaskan perbedaan TPE antarperusahaan seperti yang sudah dihipotesiskan sebelumnya.

Sementara koefisien estimasi untuk variabel CAPINT, INVINT dan ROA menunjukkan hasil yang signifikan, yang menunjukkan bahwa ketiga variabel tersebut merupakan faktor yang dapat menjelaskan variasi di dalam TPE antaperusahaan. Koefisien regresi CAPINT memiliki hubungan negatif dengan TPE yaitu -0,135 dengan t-hitung -2,837 yang signifikan pada level 1\% (uji 1 arah/onetailed test) sementara koefisien variabel INVINT memiliki hubungan positif dengan TPE yaitu 0,103 dengan t-hitung 1,648 yang signifikan pada level konvensional 5\% (uji 1 arah). Dengan demikian hasil uji regresi terhadap CAPINT dan INVINT, mengkonfirmasi $\mathrm{H}_{2}$ dan $\mathrm{H}_{3}$ penelitian ini.

Penjelasan terhadap hasil tersebut dapat didasarkan pada analisa bahwa perusahaan yang memiliki intensitas modal yang besar (yaitu perusahaan yang memiliki proporsi aset tetap bersih terhadap total aset lebih tinggi) akan memiliki kecenderungan untuk mempunyai TPE yang lebih kecil. Hal ini tidak mengherankan karena perusahaan tersebut memiliki preferensi yang cukup besar untuk meminimalkan biaya pajaknya (tax shield) melalui alokasi biaya depresiasi aset tetapnya - sehingga perusahaan-perusahaan tersebut cenderung memiliki TPE yang rendah. Hal ini berkebalikan dengan INVINT di mana perusahaan tidak memiliki preferensi tersebut, sehingga perusahaan yang memiliki proporsi sediaan terhadap total aset lebih tinggi memiliki kecenderungan memiliki TPE yang tinggi pula. Hasil uji regresi terhadap 2 variabel tersebut konsisten dengan penelitian sebelumnya, antara lain Stickney \& McGee (1982) yang menemukan bahwa intensitas modal berhubungan secara positif dengan TPE perusahaan dan penelitian Gupta \& Newberry (1992) yang menemukan bahwa TPE perusahaan-perusahaan di industri manufaktur (yang notabene memiliki proporsi sediaan yang tinggi terhadap total aset) lebih tinggi dibandingkan dengan perusahaan-perusahaan di industri perdagangan (trading).

Terakhir, untuk koefisien regresi terhadap ROA adalah -0,194 dengan t-hitung -1,925 yang signifikan pada level konvensional 5\% (uji 1 arah). Tanda negatif pada hasil uji regresi menunjukkan bahwa perusahaan yang memiliki $R O A$ lebih tinggi, akan memiliki kencenderungan TPE lebih rendah.

\section{Analisa Sensitivitas}

Uji regresi di atas tidak memasukkan variabel jenis industri sebagai variabel kontrol yang berpotensi untuk menjelaskan variasi TPE antarperusahaan. Untuk itu variabel industri dimasukkan ke dalam model (1) dan dilakukan pengujian kembali. Analisa sensitivitas dilakukan dengan memasukkan jenis industri berdasar klasifikasi yang digunakan oleh BEI. Analisa tersebut memberikan hasil yang secara kualitatif tidak berbeda dengan apa yang telah di sampaikan di Tabel 3 hasil uji regresi; dengan demikian, hasilnya tidak dicantumkan di dalam paper ini.

\section{Pengecekan Diagnostik}

Analisis dengan menggunakan regresi cross-sectional harus memenuhi beberapa asumsi klasik yaitu bahwa: (1) variance dari error term hasi uji regresi haruslah homogen (homocedasticity); (2) variance dari error term hasil uji regresi haruslah tidak berkorelasi satu sama lainnya (no autocorrelation); (3) variabel independen tidak memiliki korelasi dengan variabel dependen (no 
multicolinearity between dependent and independent variable); dan (4) sebaran error term dari hasil uji regresi haruslah terdistribusi dengan normal (normality).

Dari pengecekan diagnostik yang dilakukan, hasil uji regresi di Tabel 3 telah memenuhi asumsi klasik ke (2), (3) dan (4). Untuk homocedasticity, ditemukan bahwa variance dari error term hasil uji regresi tidaklah homogen (heteroskedastic). Hal tersebut kemudian disikapi dengan menggunakan White (1980) heteroskedasticity-consistent covariance matrix estimator di mana pengujiannya-nya lebih konservatif dibandingkan dengan uji regresi biasa (Brook, 2002), guna tetap mendapatkan hasil empiris yang valid.

\section{PENUTUP}

Penelitian ini bertujuan untuk menginvestigasi faktor-faktor yang mempengaruhi variasi tarif pajak efektif antarperusahaan. Studi dilakukan terhadap perusahaan yang terdaftar di BEI selama periode 2002 sampai dengan 2006 dengan catatan perusahaan-perusahaan tersebut mencatat laba sebelum pajak (earning before tax) positif dan mencatat biaya pajak lancar (current tax expense). Melalui pendekatan tersebut, didapat 80 perusahaan selama periode 2002-2006 yang dapat digunakan dalam pengujian, sehingga total observasi adalah 400 observasi (firm-year data).

Dengan menggunkan uji regresi cross-sectional, ditemukan bahwa perbedaan tarif pajak efektif perusahaan disebabkan adanya variasi proporsi besaran aset tetap dan sediaan terhadap total aset (capital intensity dan inventory intensity) serta tingkat perputaran aset (return on assets/ROA). Semakin tinggi proporasi besaran aset tetap terhadap total aset dan semakin tinggi tingkat perputaran aset, maka semakin rendah tarif pajak efektif perusahaan. Sebaliknya, semakin tinggi proporsi besaran sediaan terhadap total aset maka semakin tingig pula tarif pajak efektif perusahaan. Lebih lanjut, penelitian ini tidak menemukan adanya hubungan yang signifikan antara tarif pajak efektif perusahaan dengan besar kecilnya perusahaan (size) dan tingkat besaran hutang jangka panjang terhadap total aset (leverage). Namun demikian, hasil tersebut kemungkinan besar disebabkan oleh karakteristik data dari sampel perusahaan yang diteliti.

Dari sisi implikasi terhadap implementasi kebijakan sektor pajak, penelitian ini bisa digunakan sebagai dasar bagi Ditjen Pajak untuk fokus kepada perusahaan-perusahaan yang memiliki capital intensity tinggi tetapi mencatat TPE yang tinggi pula dan atau perusahaan yang memiliki inventory intensity rendah tetapi mencatat TPE yang tinggi. Anomali hubungan antara asset mix dengan TPE tersebut, bisa mengindikasikan adanya potensi pajak yang masih dapat dimaksimalkan.

Selanjutnya, dengan menggunakan analisis univariat, penelitian ini juga mendokumentasikan bahwa secara rata-rata, tarif pajak efektif perusahaan di Indonesia berada di level yang hampir sama dengan tarif pajak normal badan yaitu sebesar 30,70\%. Dengan demikian secara rata-rata perusahaanperusahaan yang diteliti telah mencatat kewajiban pajaknya sesuai dengan tarif pajak normal. Sehingga, rencana pemerintah untuk menurunkan tarif pajak sebesar 2-3\% seperti yang telah disetujui oleh DPR saat ini, dinilai sudah cukup tepat.

\section{Keterbatasan dan Penelitian Selanjutnya}

Selain beberapa temuan penelitian, studi ini juga memiliki keterbatasan yang dapat mempengaruhi interpretasi hasil penelitian. Keterbatasan ini antara lain berkaitan dengan keputusan untuk menggunakan perusahaan yang secara konsisten selama 2002-2006 memiliki laba sebelum pajak positif dan mencatat biaya pajak lancar. Persyaratan tersebut dapat memicu adanya bias bertahan (survivorship bias) dalam pemilihan sampel, di mana kecenderungannya, karakteristik perusahaan yang tersisa di dalam sampel akan menjadi tidak bervariasi (antara lain: sampel terdiri dari perusahaan-perusahaan besar saja). 
Namun demikian, penelitian ini tetap menjadi penting karena menjadi jalan pembuka penelitian selanjutnya, berkaitan dengan perhitungan TPE perusahaan. Penelitian selanjutnya yang bisa dilakukan antara lain: mencoba menjawab pertanyaan, apakah variasi TPE sebagai tolok ukur sukses tidaknya tax planning dipengaruhi juga oleh besar kecilnya investasi perusahaan dalam bidang perpajakan, termasuk di dalamnya apakah menggunakan konsultan perpajakan dari pihak eksternal, memiliki pengaruh yang signifikan terhadap besar kecilnya TPE. Selanjutnya, juga bisa dilakukan penelitian berkaitan dengan manajemen laba melalui biaya pajak, antara lain dengan cara mengukur perubahan tarif pajak efektif perusahaan dari kuartal tiga ke ke kuartal empat (akhir tahun) dan pengaruhnya terhadap TPE dalam periode yang sama.

\section{DAFTAR PUSTAKA}

Brook, C. (2002). Introductory econometrics for finance (1st ed.). Cambridge University Press, Cambridge.

Callihan, D. (1994). Corporate effective tax rates: A synthesis of literature. Journal of Accounting Literature 13: 1 - 43.

Dhaliwal, D., Gleason, C., \& Mills, L. (2004). Last chance earnings management: using the tax expense to meet analysts’ forecasts. Contemporary Accounting Research 21 (2): 431-457.

Gupta, S., \& Newberry, K. (1992). Corporate average effective tax rate after the tax reform Act of 1986. Tax Notes, May 4: 689-702.

Gupta, S., \& Newberry, K. (1997). Determinants of the variability in corporate tax rates: Evidence from longitudinal data. Journal of Accounting and Public Policy, 16: 1-34.

Klassen, K. J. (1996). The impact of inside ownership concentration on the trade-off between financial and tax reporting. Working paper, University of Waterloo.

Mills, L., Erickson, M., \& Maydew, E. (1998). Investments in tax planning. The Journal of the American Taxation Association 20 (1): 1-20.

Radianto, W. E. D. (2004). Analisis efisiensi perusahaan bank yang terdaftar sebelum dan sesudah diberlakukannya Undang-Undang Perpajakan 2000. Prosiding Seminar Nasional Akuntansi VII, Denpasar, 2-3 Desember 2004.

Republik Indonesia. (1994). Undang-Undang nomor 10 tahun 1994 tentang Perubahan Kedua Atas Undang-Undang Nomor 7 Tahun 1983 Tentang Pajak Penghasilan. Sekretariat Negara, Jakarta.

Republik Indonesia. (2000). Undang-Undang nomor 17 tahun 2000 Undang-Undang tentang Perubahan Ketiga Atas Undang-Undang Nomor 7 Tahun 1983 Tentang Pajak Penghasilan. Sekretariat Negara, Jakarta, 2 Agustus 2000.

Schmidt, A. (2006). Tax persistence, forecasting ability, and valuation implications of the tax change component of earnings. The Accounting Review 81, 589-616.

Siegfried, J. (1972). The relationship between economic structure and the effect of political influence: Empirical evidence from the federal corporation income tax program. $\mathrm{PhD}$ Thesis. University of Wisconsin. 
Stickney, C. P., \& McGee, V. (1982). Effective tax rates: The effect of size, capital intensity, leverage and other factors. Journal of Accounting and Public Policy, 1: 125-152.

Shevlin, \& Porter. (1992). The Corporate Tax Rate Comeback in 1987: Some further evidence. The Journal of the American Taxation Association 14 (1): 58 - 79.

Watts, R., \& Zimmerman, J. (1986). Towards a Positive Theory of Accounting. Englewood Cliffs, NJ: Prentice-Hall.

White, H. (1980). A heteroskedasticity-consistent covariance matrix estimator and a direct test for heteroskedasticity. Econometrica 48(4): 817-838.

Wulandari, D., Kumalahadi., \& Prasetyo J. E. (2004) Indikasi Manajemen Laba Menjelang UndangUndang Perpajakan 2000 pada Perusahaan Manufaktur Yang Terdaftar di Bursa Efek Jakarta, Prosiding Seminar Nasional Akuntansi VII, Denpasar, 2-3 Desember 2004. 